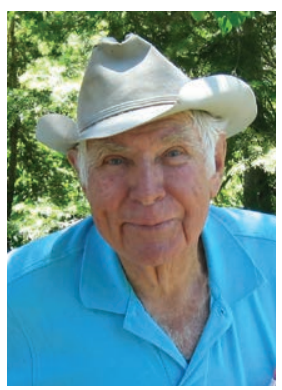

By Thad Box

\title{
Learning at Unexpected Times in Unlikely Places
}

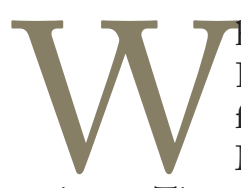

Then I was young, years ago — decades ago, actually - I attended a Danforth Fellows Conference on improving the effectiveness of college teachers. The featured instructor was Albert C. Outler, a famous theologian from Southern Methodist University. He was billed as one of the leading scholars on Biblical authority. The program listed an impressive sample of his publications, mostly on quadrilateral methodology for theological reflection based on four sources: scripture, tradition, experience, and reason. The people around me were from the arts-as alien to me as if they were from Mars.

The program didn't appear to offer much for a young range management professor, but the Danforth Foundation was paying my expenses and I felt obligated to attend. When Dr Outler was introduced, he walked to the blackboard and wrote (that was long before power point presentations): "Luke 10:19, 'Behold, I have given you authority to tread on serpents and scorpions, and over all the power of the enemy, and nothing shall hurt you."

As I began to look for ways to escape without being seen, Dr Outler said that our effectiveness as teachers would depend on how we handled authority. Our positions at respective universities gave us temporary authority over people called students. Our training, reading, and experience made us authorities on our particular field. Our success as a teacher would depend on balancing "authority on" with "authority over." He had me hooked.

Using a series of examples he told us that we had to continue to study and learn so that our authority on our subject would be current and as accurate as possible. We would succeed only when we were able to transfer our knowledge and our skills to our students. We had to give those who we had authority over, other people and things, the most accurate information possible.

Authority over students came with the responsibility to make them authorities on whatever we taught. Our job was to give information to them. But to be effective we had to do it in a language and in a cultural context they could understand. If our authority over students came across as harsh and dictatorial, it made transfer of knowledge more difficult. When authority over was demonstrated by caring, understanding, and love, students learned and retained more of what was being taught. When authority over is used to punish or embarrass, it causes resentment and little knowledge is transferred.

Being a minister and theologian, he made those points by contrasting the demanding and vindictive god of the Old Testament and the love of the New Testament. His message made so much sense that I tolerated all the Bible stuff. He was putting ideas in my head that made me think.

Today, many range managers, foresters, wildlife biologists, geologists, geographers, and other land care professionals are frustrated. They have invested their time to learn their profession, but are unable to implement what they know. They feel boxed in by bureaucracy and criticized by special interest groups. I think an understanding of authority on and authority 
over could be useful in their toolbox as they work in controversial areas such as public land management.

Where land is privately owned, land care professionals may work as a Natural Resources Conservation Service specialist, a county agent, or a consultant. The ability to get even simple things done, like a soil conservation plan, depends on harmony between authority over and authority on. Trust between owner and land care professional is essential. That trust comes from shared knowledge and responsibility.

Land care professionals have little authority over people who own the land. Their role is being an authority on the land. Their authority comes from knowledge - in having information, concepts, and skills the owner of the land does not have. But the landowner has experiential knowledge that the professional does not have. He also depends on the land for his economic well-being. And as the owner, he has authority over the land. The relationship between expert and owner can be simple and straightforward if they respect each other's strengths.

The work of land care professionals is more difficult and complicated when land is publicly owned. Lacking a single owner to make decisions about land use and system health, rules and regulations are drafted for various land uses, use is rented to a permittee, and an administrator is assigned to coordinate them. The "authority on" a given land use usually comes from a staff specialist trained in that field.

The "authority over" public land uses is not a human being, but regulations written by people (some with authority on specific parts of the system), coordinated by system specialists, modified by legal experts to conform with specific laws, and implemented by an administrator. "Authority on" of permittees varies greatly; their "authority over" is limited to following regulations.

The public land management system is further complicated by lobbyists and true believers in ever-growing mobs of special interest organizations-energy developers, feral horse lovers, wilderness organizations, off-road vehicle clubs, hunters, fishermen, save-the-whatever nonprofit groups-each trying to get the public land used for their cause. Added to this are politicians who want to take the public land from the people and sell it to investors. Strength of these would-be "authorities over" comes from their ability to raise money, buy influence, and isolate or negate the influence of "authorities on" the land.

Leaders of these groups are often lacking in "authority on" any aspect of land. Their self-proclaimed "authority over" the land comes from beliefs, not facts, making them more akin to religion than science. I am not a religious person, but I'm not above using tools developed by those who are. Dr Outler became famous for his quadrilateral methodology for theological reflection based on scripture, tradition, experience, and reason. Perhaps his methodology can be applied to land management.

Our scripture consists of scientific facts, some documented in publications, others still hiding in ancient rocks, in ocean depths, and in communities of small organisms we cannot see. As our knowledge grows, our "authority on" increases and makes it possible to gain "authority over" some parts and functions of land. We use our traditions in applying that authority to make the newly modified system sustainable. We learn from past success and failures. And we apply our developing knowledge with reason, doing those things we think right, practical, and possible.

I look out my window at snow-covered mountains of the Bear River Range. A hundred and ten years ago, they were overgrazed, overcut, and barren. Mud slides from them covered towns and villages. Local people petitioned the government to put them in a forest reserve. The Cache National Forest was born. As science developed by land managers was applied, the land healed and the forest returned.

Some politicians are trying to get the land privatized and "developed." If that were to happen roads would creep up the valleys, McMansions grow on the cliffs, swimming pools nestle among the aspens, and developers become wealthy. Geology and history, our scriptures, suggest that eventually, the mountains will shed their skin of human development, and landowner's dreams will slide down the mountains and cover other houses sitting on ancient rubble from multiple landslides of the past.

Our writings, tradition, experience, and reason warns us that a clear title registered in the courthouse does not prevent our use of that land from becoming a disaster. We can become authorities on land, but we never truly have authority over it. Land does not belong to us, we belong to the land.

\section{ThadBox, thadbox@comcast.net.}

Rangelands 36(6):44-45

doi: 10.2111/Rangelands-D-14-00019.2

(c) 2014 The Society for Range Management 